\title{
Identification and characterization of PhbF: A DNA binding protein with regulatory role in the PHB metabolism of Herbaspirillum seropedicae SmR1
}

\author{
Marco AS Kadowaki ${ }^{1}$, Marcelo Müller-Santos ${ }^{1}$, Fabiane GM Rego ${ }^{2}$, Emanuel M Souza ${ }^{1}$, Marshall G Yates ${ }^{1}$,
} Rose A Monteiro ${ }^{1}$, Fabio O Pedrosa', Leda S Chubatsu ${ }^{1}$ and Maria BR Steffens ${ }^{1 *}$

\begin{abstract}
Background: Herbaspirillum seropedicae SmR1 is a nitrogen fixing endophyte associated with important agricultural crops. It produces polyhydroxybutyrate (PHB) which is stored intracellularly as granules. However, PHB metabolism and regulatory control is not yet well studied in this organism.

Results: In this work we describe the characterization of the PhbF protein from H. seropedicae SmR1 which was purified and characterized after expression in E. coli. The purified PhbF protein was able to bind to eleven putative promoters of genes involved in PHB metabolism in H. seropedicae SmR1. In silico analyses indicated a probable DNA-binding sequence which was shown to be protected in DNA footprinting assays using purified PhbF. Analyses using lacZ fusions showed that PhbF can act as a repressor protein controlling the expression of PHB metabolismrelated genes.

Conclusions: Our results indicate that $H$. seropedicae SmR1 PhbF regulates expression of phb-related genes by acting as a transcriptional repressor. The knowledge of the PHB metabolism of this plant-associated bacterium may contribute to the understanding of the plant-colonizing process and the organism's resistance and survival in planta.
\end{abstract}

\section{Background}

Polyhydroxyalkanoates (PHA) are aliphatic polyesters biosynthesized by several bacteria [1-4] as a means of carbon storage and a source of reducing equivalents when other nutrients are limiting. The most frequently PHA produced is poly(3-hydroxybutyrate) or PHB [2]. The ability to produce PHB has been correlated with improved survival under stress conditions or in competitive environments $[5,6]$. PHB is generally produced in conditions of carbon oversupply and low levels of other nutrients such as nitrogen, phosphate or oxygen [7]. The biosynthesis of PHB is dependent on the activity of the following enzymes: (i) a 3-ketothiolase which condenses two acetyl-CoA yielding acetoacetyl-CoA (encoded by

\footnotetext{
* Correspondence: steffens@ufpr.br

'Department of Biochemistry and Molecular Biology, Universidade Federal

do Paraná, Curitiba - PR, Brazil

Full list of author information is available at the end of the article
}

$p h b A$ ), (ii) a NADPH-dependent acetoacetyl-CoA reductase which reduces acetoacetyl-CoA to (R)-3-hydroxybutyryl-CoA (encoded by $p h b B$ ) and (iii) the PHB synthase (encoded by $p h b C$ ) that catalyses the polymerization of (R)-3-hydroxybutyryl-CoA to form the polymer $[8,9]$. This polymer is stored intracellularly as insoluble inclusion bodies called PHB granules [1] which also contain about $2 \%$ protein as well as phospholipids [10]. The main protein associated with the PHB granules is phasin (encoded by phaP) which prevents coalescence of PHB granules by coating the granule surfaces [11-14]. However, other proteins have also been found associated with the granules, including transcriptional regulators such as PhaF from Pseudomonas oleovorans GPo1, PhaR from Paracoccus denitrificans, and PhaR from Ralstonia eutropha $\mathrm{H} 16$ [15-17].

Expression of enzymes involved in PHA/PHB biosynthesis and the granule-associated phasin are reported to be

\section{Ciomed Central}


regulated at the transcriptional level $[15,16,18-26]$. This regulation may include repressors as well as activators [21]. The proteins PhbR from Azotobacter vinelandii UW136 [22] and PhaD from Pseudomonas putida KT2442 [24] are transcription activators. In contrast, PhaR of $P$. denitrificans represses phaR expression by binding to a TGC rich region which overlaps the $-35 /-10$ promoter [16]. In $R$. eutropha $\mathrm{H} 16$ the PhaR protein binds to the $-35 /-10$ phaP promoter at two sites: the transcriptional start site and upstream from the -35 at the promoter region, thereby blocking RNA polymerase [17]. The PhaR binding site determined in R. eutropha comprises two 12 bp repeated sequences not related to those observed in P. denitrificans, suggesting that DNAbinding sites for PhaR recognition and the mechanisms of regulation may vary.

The $\beta$-Proteobacterium Herbaspirillum seropedicae SmR1 is a plant-endophytic diazotroph found in association with economically important graminaceous species such as sugar cane, sorghum, rice and maize [27]. $H$. seropedicae SmR1 has been already described as a PHB producer using glucose as carbon source [28], however the molecular aspects of its PHB metabolism have not been addressed. The H. seropedicae SmR1 genome sequence analysis indicated several genes likely to be involved in PHB metabolism, including, $p h b A$, phbB and $p h b C$ encoding for 3-ketothiolase, acetoacetyl-CoA reductase and poly(3-hydroxybutyrate) synthase. The $p h b F$ gene encoding a putative regulator was located downstream from $p h b C B$ [29]. In this work we characterized the transcriptional regulator PhbF of Herbaspirillum seropedicae SmR1.

\section{Methods}

\section{Strains and plasmids}

All bacterial strains and plasmids used in this work are listed in Table 1.

\section{Media and growth conditions}

Escherichia coli strains were grown in LB or M9 minimal media at $37^{\circ} \mathrm{C}$ [30]. The $H$. seropedicae SmR1 strain was grown at $30^{\circ} \mathrm{C}$ in NFbHPN-Malate medium supplemented with $20 \mathrm{mM} \mathrm{NH}_{4} \mathrm{Cl}$ [31]. Antibiotics were added as follows: ampicillin $100 \mu \mathrm{g} \cdot \mathrm{mL}^{-1}$, tetracycline $10 \mu \mathrm{g} \cdot \mathrm{mL}^{-1}$, streptomycin $20 \mu \mathrm{g} \cdot \mathrm{mL}^{-1}$ (E. coli) or $80 \mu \mathrm{g} \cdot \mathrm{mL}^{-1}$ (H. seropedicae SmR1), kanamycin $50 \mu \mathrm{g} \cdot \mathrm{mL}^{-1}($ E. coli) or $500 \mu \mathrm{g}$. $\mathrm{mL}^{-1}$ (H. seropedicae SmR1), chloramphenicol $30 \mu \mathrm{g} \cdot \mathrm{mL}^{-}$

${ }^{1}$ (E. coli) or $150 \mu \mathrm{g} \cdot \mathrm{mL}^{-1}$ (H. seropedicae SmR1) and nalidixic acid $10 \mu \mathrm{g} \cdot \mathrm{mL}^{-1}$.

\section{Plasmid Construction}

The $p h b F$ gene was amplified from the H. seropedicae SmR1 genome using the primers 5'GACTGGACTTCATATGACTACTGC3' and 5'CAACAGGATCCGGC
AGAATG3' carrying NdeI or HindIII restriction sites (underlined). The amplified product was cloned into pET-28a to yield plasmid pKADO3, which overexpresses the PhbF protein fused to an N-terminal sixhistidine tag (His-PhbF). To express PhbF from a tac promoter, $p h b F$ was obtained in an XbaI/HindIII fragment from pKADO3 and cloned into pDK6, yielding plasmid pMMS31.

\section{Construction of transcriptional fusions phbF::lacZ and phaP1::lacz}

The promoter regions of $p h b F$ (containing $353 \mathrm{bp}$ including 54 bp of the $p h b F$ coding sequence) and phaP1 (containing $381 \mathrm{bp}$ including $28 \mathrm{bp}$ of the phaP1 coding sequence) were amplified from the $H$. seropedicae SmR1 genome and cloned into pMP220 [32], upstream from the promoter-less lac $Z$ gene to yield the respective plasmids pKADO5 and pMMS35.

\section{$\beta$-galactosidase activity assay}

$\beta$-galactosidase activity was determined in E. coli ET8000 carrying transcriptional fusion plasmids (pKADO5 or pMMS35), in the presence or absence of plasmid pMMS31 (expresses PhbF), grown in M9 minimal medium as described [33]. Protein concentration was determined using the Bradford method [34] with bovine serum albumin as standard.

\section{In silico identification of DNA motif}

The MEME program [35] was used to detect a common motif among promoter regions of genes related to PHB metabolism in the H. seropedicae SmR1 genome [29]. The MEME program was set to identify not more than one motif with 6 to $50 \mathrm{bp}$ in length. The conserved motif was represented in the LOGO format

\section{Purification of His-PhbF}

E. coli strain BL21 (DE3) carrying pKADO3 was grown in $\mathrm{LB}$ medium at $37^{\circ} \mathrm{C}$ to an $\mathrm{OD}_{600}$ of $0.6-0.8$. The culture was then induced with $0.5 \mathrm{mmol} / \mathrm{L}$ IPTG at $20^{\circ} \mathrm{C}$ for 15 hours. After harvesting, cells were lysed by sonication in buffer A (100 mmol/L NaCl, 50 mmol/L Tris- $\mathrm{HCl}$ pH 7.5, $10 \mathrm{mmol} / \mathrm{L}$ imidazole and $0.05 \%$ Triton X-100). After clarification by centrifugation at $14000 \times g$ for 30 minutes at $4{ }^{\circ} \mathrm{C}$, the protein extract was loaded onto a Hi-Trap Chelating $\mathrm{Ni}^{2+}$ column (GE Healthcare). Protein elution was carried out using a linear imidazole gradient, and His$\mathrm{PhbF}$ was eluted with $300 \mathrm{mmol} / \mathrm{L}$ imidazole in buffer A. Protein fractions were pooled and, after dialysis against buffer A with $50 \%$ glycerol, were stored in liquid $\mathrm{N}_{2}$.

\section{Electrophoretic Mobility Shift Assay (EMSA)}

The promoter regions of genes related to PHB biosynthesis were amplified using fluorescent (VIC and FAM) 
Table 1 Strains and plasmids used in this work

\begin{tabular}{|c|c|c|}
\hline Strains & Relevant genotype & Reference/source \\
\hline \multicolumn{3}{|l|}{ E. coli } \\
\hline BL21(DE3) & hsdS gal (גclts 857 ind1 Sam7 nin5 lacUV5-T7 gene 1). & Invitrogen \\
\hline ET8000 & rbs lacZ::IS1 gyrA hutCc $k$ (wild-type). & [42] \\
\hline \multicolumn{3}{|c|}{ H. seropedicae } \\
\hline SmR1 & Wild-type, $\mathrm{Nif}^{+}, \mathrm{Sm}^{\mathrm{R}}$. & [43] \\
\hline \multicolumn{3}{|l|}{ Plasmids } \\
\hline pET-28a & Expression vector, $\mathrm{T7}$ promoter, $\mathrm{Km}^{\mathrm{R}}$. & Novagen \\
\hline pDK6 & Expression vector tac promoter laclq, $\mathrm{Km}^{\mathrm{R}}$. & [44] \\
\hline pKADO3 & H. seropedicae SmR1 phbF cloned into pET-28a; expresses the His-tag PhbF protein. & This work \\
\hline pKADO5 & 353 bp containing phbF promoter region cloned into pMP220 resulting in the phbF:: lacZ transcriptional fusion. & This work. \\
\hline pMMS31 & Derivative of pDK6 encoding PhbF from H. seropedicae SmR1. & This work. \\
\hline pMMS35 & 381 bp containing phaP1 promoter region cloned into pMP220 resulting in the phbP1:: lacZ transcriptional fusion. & This work. \\
\hline pMP220 & Vector used to construct transcriptional lacZ fusions; $T c^{R}$. & [32] \\
\hline
\end{tabular}


end-labeled primers. Alternatively, $p h b F$ and $p h a P 1$ promoters were amplified and end-labeled using $\left[{ }^{32} \mathrm{P}\right] \gamma$-ATP and T4 polynucleotide kinase [30]. DNA-binding assays were performed in $10 \mu \mathrm{L}$ containing $20 \mathrm{nmol} / \mathrm{L}$ of endlabeled DNA, $100 \mathrm{ng}$ of calf thymus DNA, and increasing amounts of purified His-PhbF in binding buffer $(10 \mathrm{mmol} / \mathrm{L}$ Tris- $\mathrm{HCl} \mathrm{pH} 7.5,80 \mathrm{mmol} / \mathrm{L} \mathrm{NaCl}$, $1 \mathrm{mmol} / \mathrm{L}$ EDTA, $10 \mathrm{mmol} / \mathrm{L} \beta$-mercaptoethanol and $5 \%(\mathrm{~m} / \mathrm{v})$ glycerol $)$ following incubation at $30^{\circ} \mathrm{C}$ for 5 minutes. The fluorescent DNA was observed after excitation with UV light $(254 \mathrm{~nm})$ and the $\left[{ }^{32} \mathrm{P}\right]$-labeled DNA was detected using a PhosphorImager screen and a STORM scanner.

\section{DNasel footprinting assay}

A 325bp DNA fragment containing the $p h b F$ promoter region was amplified using $\left[{ }^{32} \mathrm{P}\right]$-labeled primer and genomic DNA as template [30]. The fragment was purified using the Wizard kit (Promega) and then incubated with His-PhbF in $50 \mathrm{mmol} / \mathrm{L}$ Tris-acetate $\mathrm{pH} 8.0,8 \mathrm{mmol} / \mathrm{L}$ magnesium acetate and $10 \mathrm{mmol} / \mathrm{L} \mathrm{KCl}$ at $30^{\circ} \mathrm{C}$ for $5 \mathrm{~min}$ utes. For partial hydrolysis, 1 unit of DNaseI (Invitrogen) was added and the reaction incubated at $30^{\circ} \mathrm{C}$ for $1 \mathrm{~min}$ ute. The reaction was stopped by adding 0.2 volume of $0.5 \mathrm{mmol} / \mathrm{L}$ EDTA and heating at $80^{\circ} \mathrm{C}$ for 5 minutes. After ethanol precipitation of DNA fragments in the presence of yeast tRNA, samples were solubilized in $6 \mu \mathrm{L}$ of loading buffer (47\% formamide (v/v), $10 \mathrm{mmol} / \mathrm{L}$ EDTA, 0.05\% bromophenol blue $(\mathrm{m} / \mathrm{v}), 0.05 \%$ xylene xyanol $(\mathrm{m} /$ $\mathrm{v})$ ), denatured at $80^{\circ} \mathrm{C}$ for 5 minutes and loaded on a $6 \%$ $(\mathrm{m} / \mathrm{v})$ polyacrylamide denaturing DNA sequencing gel [30]. The $p h b F$ promoter region was sequenced using the T7 sequencing kit (GE Healthcare). Images of the autoradiograms were obtained using a PhosphorImager screen and a Storm scanner. Densitrometric profiles were analyzed using the ImageQuant v.5.2 program (Molecular Dynamics).

\section{Extraction of PHB granules}

PHB granules were extracted from H. seropedicae SmR1 grown in NFbHP-malate medium containing $5 \mathrm{mM}$ glutamate at $30^{\circ} \mathrm{C}$ until $\mathrm{OD}_{600}=1.0$, following a described procedure [36]. After extraction, granules were washed twice with water and then with acetone. Granules were dried under a nitrogen gas stream at room temperature and stored at $-20^{\circ} \mathrm{C}$.

\section{PHB granule-binding of the His-PhbF protein}

The PHB granule-binding reaction was performed as described [37] with modifications. His-PhbF $(25 \mu \mathrm{g})$ was incubated with $1 \mathrm{mg}$ of purified $H$. seropedicae SmR1 PHB granules in a final volume of $100 \mu \mathrm{L}$ in $50 \mathrm{mmol} / \mathrm{L}$ Tris- $\mathrm{HCl} \mathrm{pH} \mathrm{7.5.} \mathrm{Samples} \mathrm{were} \mathrm{incubated} \mathrm{at} 37^{\circ} \mathrm{C}$ for 10 minutes and then centrifuged at $10,000 \times \mathrm{g}$ for
1 minute. The supernatant was collected and the granules were washed twice with $400 \mu \mathrm{L}$ of $50 \mathrm{mM}$ Tris- $\mathrm{HCl}$ pH 7.5 and the supernatant from each wash step was also collected separately. Protein bound to the granules was dissociated by incubation in $2 \%(\mathrm{~m} / \mathrm{v})$ SDS, $10 \%(\mathrm{~m} / \mathrm{v})$ glycerol and $5 \%(\mathrm{~m} / \mathrm{v}) \beta$-mercaptoethanol at $90^{\circ} \mathrm{C}$ for five minutes. Samples were analyzed by SDS-PAGE [38].

\section{Results and discussion}

The H. seropedicae SmR1 PhbF protein was first identified in the cellular proteome by [39] using late log phase culture grown under ammoniotrophic conditions. The $p h b F$ gene (H_sero2997) is located downstream from $p h b C$ and phbB (GenBank: CP002039) and encodes a 188 amino acids protein with high similarity to $R$. eutropha H16 PhaR (183 amino acids, 83\% identity, 90\% similarity) [17], and, to a lesser extent, to Rhodobacter sphaeroides FJ1 (41\% identity and 59\% similarity) and P. denitrificans PhaR (restricted to the N-terminus with 37\% identity and 56\% similarity to the first 120 amino acids). In silico analysis indicated a helix-turn-helix motif located at its $\mathrm{N}$-terminal sequence suggesting that $\mathrm{PhbF}$ is capable of DNA-binding and may act as a regulator of PHB biosynthesis genes in H. seropedicae SmR1.

To characterize the H. seropedicae SmR1 PhbF protein, it was overexpressed and purified as a His-tag fusion form (His-PhbF) from E. coli BL21(DE3) harboring the plasmid pKADO3 (Table 1). Most of the expressed His-PhbF was found in the soluble protein fraction when cells were induced at low temperature $\left(20^{\circ} \mathrm{C}\right)$ and lysed in buffer containing Triton X-100 0.05\% (m/v). This detergent at low concentration yielded a homogenous His-PhbF protein solution of $98 \%$ purity by $\mathrm{Ni}^{2+}$-affinity chromatography. Circular dichroism analysis indicated that purified His-PhbF is folded in the presence of the detergent (Additional file 1, Figure S1). Also, gel filtration chromatography indicated that $H$. seropedicae SmR1 PhbF is tetrameric in solution with an apparent molecular weight of $104.3 \mathrm{kDa}$ (Additional file 1, Figure S2). The PhaR from P. denitrificans is also a tretrameric protein of approximately $95 \mathrm{kDa}$ in solution [16].

Twelve putative promoter regions were identified by DNA sequence analyses of genes potentially involved in PHA metabolism in H. seropedicae SmR1 (GenBank: CP002039, [29]) as shown in Additional file 1, Figure S3. All of these putative promoter regions, with the exception of phaP2, were assayed for DNA binding by HisPhbF. DNA band-shift assays showed that purified HisPhbF was able to bind specifically to these eleven promoter regions (Figure 1 and results not shown) but not to the unrelated nifB promoter [40](Additional file 1, Figure S4) indicating that the protein is active. The apparent dissociation constants observed varied from $150 \mathrm{nM}$ (phaP1) to $450 \mathrm{nM}$ (phbF). 

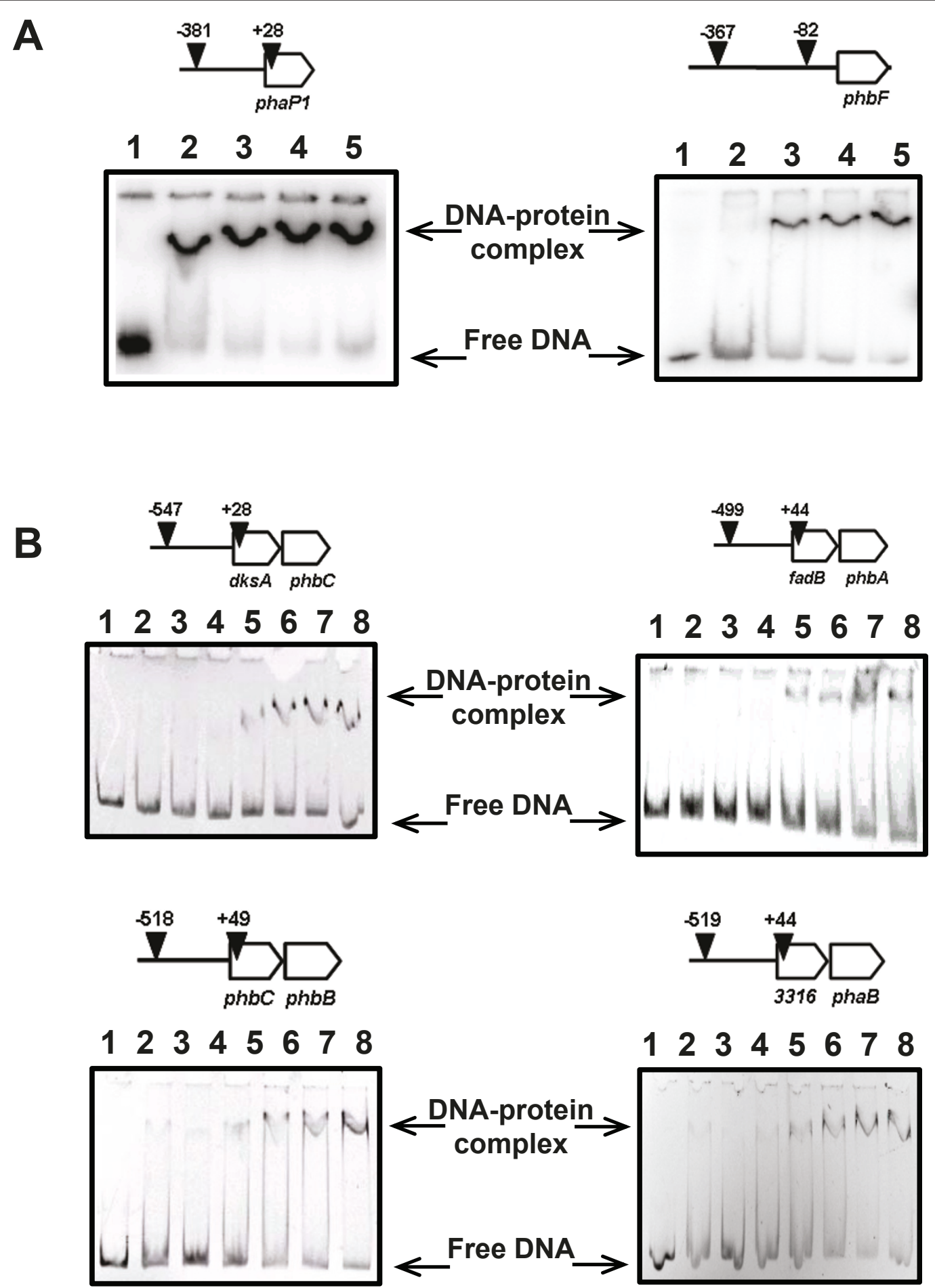

Figure 1 The DNA-binding assays of purified His-PhbF from $H$. seropedicae SmR1 to the promoter regions of phaP1, phbF, dskAphbC, fadBphbA, phbCphbB and $H \_s e r o 3316 p h a B$ were performed as described in Material and Methods. DNA promoter regions used in the assays are indicated by vertical black arrow heads and numbers indicate base position related to the translation start of each gene. Panel A: DNA labeled with $\left.{ }^{32} \mathrm{P}\right]$. Lanes 1 to 5 indicate increasing amounts of purified His-PhbF (0, 280, 570, 860 or $\left.1100 \mathrm{nM}\right)$. Panel B: Fluorescent labeled DNA. Lanes 1 to 8 indicate increasing amounts of purified $\operatorname{His-PhbF}(0,62,125,250,500,750,1000$ or 1250 nM). Protein concentrations were calculated assuming His-PhbF as a tetrameric protein. 
These twelve promoter regions (including phaP2, additional file 1, Figure S3) were also analyzed in silico using the MEME program [35] which indicated the sequence TG[N]TGC[N] $]_{3}$ GCAA as a probable DNA-binding motif for PhbF (Figure 2A). A similar sequence (CTGC[N] ${ }_{3}$ GCAG) was also described in $R$. sphaeroides FJ1 as the DNA-binding site for the regulator PhaR [41]. Both sequences show two highly conserved triplets (TGC and
GCA) which seem to be essential for DNA-binding of $R$. sphaeroides PhaR [41].

To verify if the TG[N]TGC[N] $]_{3}$ GCAA sequence is important for DNA-binding of $H$. seropedicae SmR1 $\mathrm{PhbF}$, a DNaseI footprinting assay was performed using the $p h b F$ promoter region and purified His-PhbF (Figure 2B). A clear DNaseI protection site was observed when His-PhbF was present in the assay. The protected site

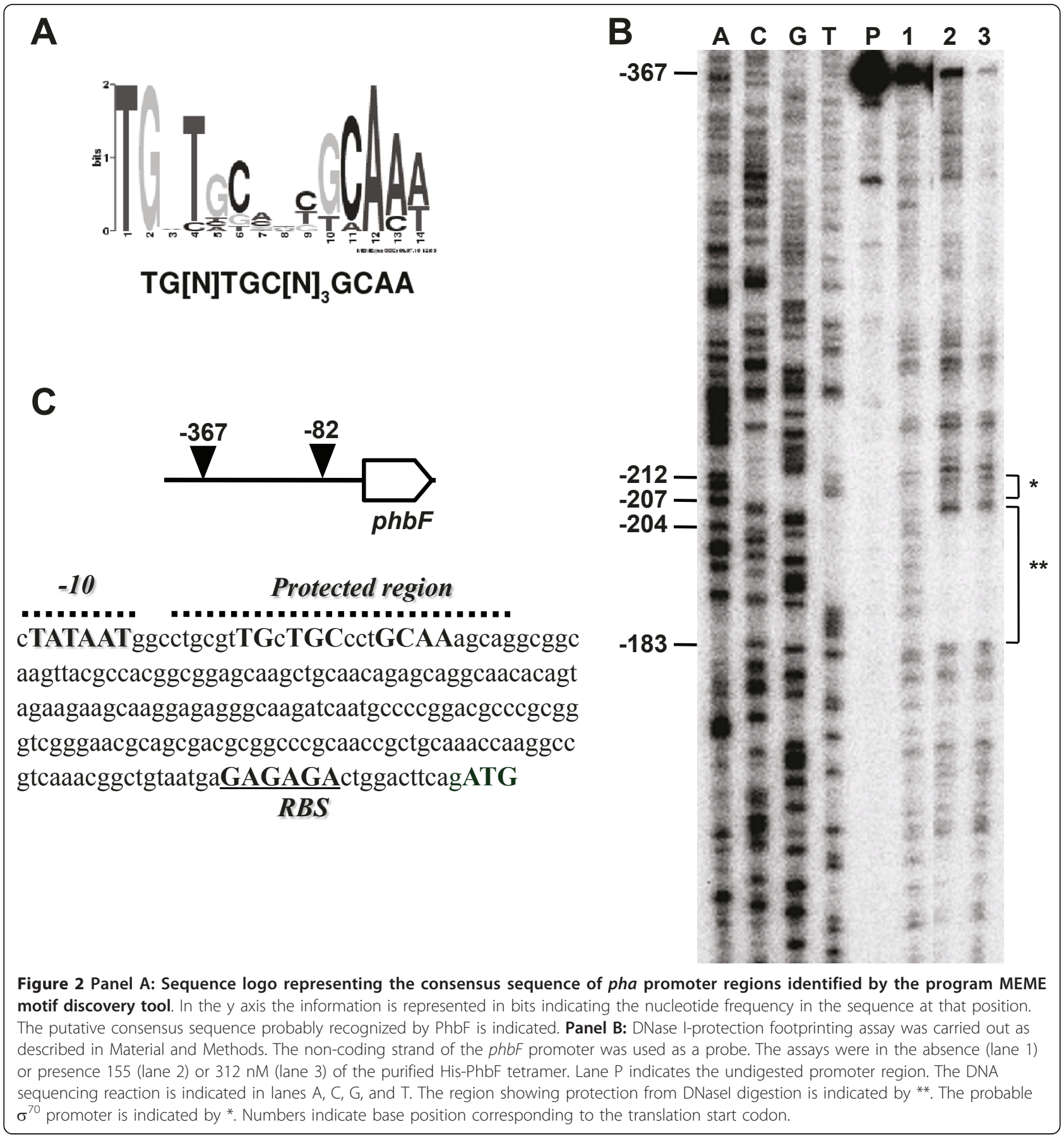


covers positions 181 to 204 upstream from the translation start site indicating that His-PhbF binds to a $24 \mathrm{bp}$ region of its own promoter which includes the conserved TG[N]TGC[N] $]_{3}$ GCAA motif indicated by the MEME program, reinforcing the suggestion that it is the DNA site recognized by the $H$. seropedicae SmR1 PhbF. Furthermore, a putative sigma 70-dependent promoter was also identified upstream from the PhbF DNA-binding site (position 208 to 212 from the translation start site) (Figure 2C). The proximity of both sites also suggests that $H$. seropedicae SmR1 PhbF may repress its own expression.

We verified the potential repressor activity of PhbF in E. coli ET8000 by using a gene reporter expression assay with $p h a P 1$ and $p h b F$ promoters fused to the lacZ gene. These genes were chosen because they have the putative PhbF-binding sequence highly similar to the consensus sequence, and also because EMSA assay showed clear interaction with these promoters. The $\beta$-galactosidase activities indicated that both phaP1 and $p h b F$ promoters were functional in E. coli (Figure 3). However, a clear decrease in $\beta$-galactosidase activity is observed if $H$. seropedicae SmR1 PhbF is present (expressed upon plasmid pMMS31), indicating that PhbF represses the expression of the phasin gene (phaP1) and also of its own gene promoter $(p h b F)$. Expression of an unrelated protein $(\mathrm{NifH})$ did not affect $\beta$-galactosidase activity of $E$. coli bearing the phbF:: lac $Z$ and phaP1::lacZ fusions (data not shown), reinforcing the repressor effect of PhbF.

Protein domain analysis indicated that PhbF contains a DNA-binding motif and a domain possibly involved in

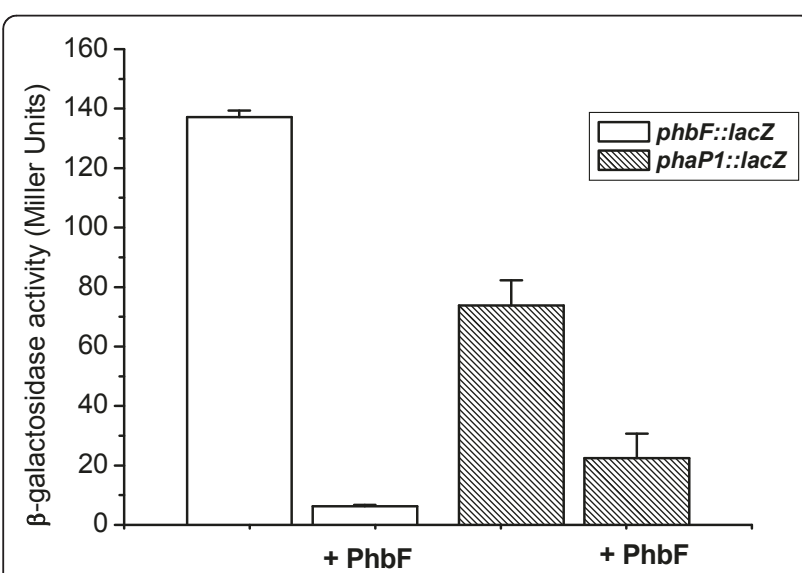

Figure $3 \beta$-galactosidase activity of $E$. coli strain ET8000 carrying phbF::IacZ or phbP1::IacZ fusion (plasmids pKADO5 and pMMS35, respectively). Assays were performed as described in Material and Methods. The His-PhbF protein was expressed by the tac promoter from the plasmid pMMS31. Data represents the average \pm standard deviation of at least three independent determinations. Background activity of cells carrying pMP220 (control vector) in the presence of pMMS31 was less than 6 Miller units. binding PHB. Therefore, we tested if $H$. seropedicae SmR1 PhbF was able to interact with PHB granules in vitro. The purified His-PhbF was incubated with $\mathrm{PHB}$ granules extracted from $H$. seropedicae SmR1 and the protein remaining in solution was visualized by SDSPAGE (Figure 4). When His-PhbF was incubated with PHB granules most of the protein was extracted from solution (Figure 4, lane 2). The protein remained bound to the granule even after two washing steps (lanes 3 and 4 ), and was released only after heating in the presence of SDS, indicating a strong interaction between His-PhbF and PHB.

Our results indicate that $H$. seropedicae SmR1 PhbF is capable of DNA binding and also of associating with PHB granules. In addition, expression of PhbF from $H$. seropedicae SmR1 leads to 10 and 4-fold reduction $(\mathrm{P}<0.05)$ in expression of $p h b F$ and $p h a P 1$ promoters, respectively. These results strongly suggest that $H$. seropedicae SmR1 $\mathrm{PhbF}$ protein is a repressor which controls expression of genes involved in PHB production as well its own expression. In both respects it shows similarity with the PhaR regulator from $R$. eutropha [17] and from $P$. denitrificans [16].

The expression of $p h b F$ gene in H. seropedicae SmR1 increases sharply in the log phase (not shown) and PHB starts to accumulate in the log phase reaching maximum as the culture entry in the stationary phase [28], suggesting that the repressor activity of PhbF may be relieved as PHB oligomers levels increase inside the cell, as suggested in $R$. eutropha and $P$. denitrificans $[11,16,17]$. The expression of phaP1 has a similar pattern. We hypothesize that when

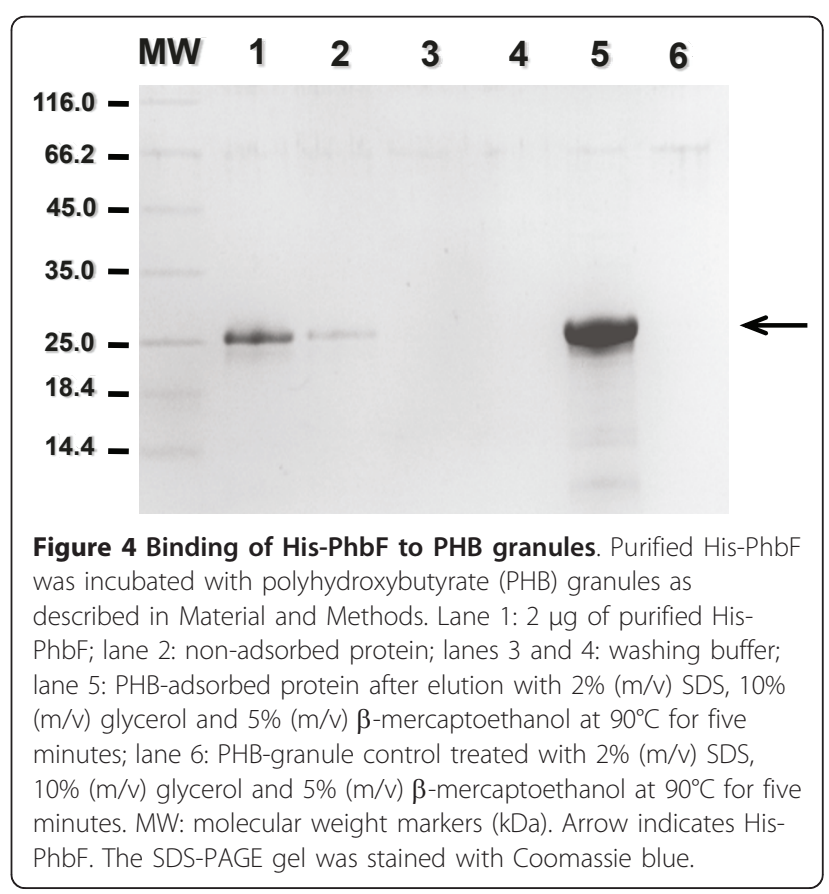


PHB oligomers levels increase, the PhbF protein is sequestred, allowing transcriptional initiation. Whether PhbF can be released from DNA by binding to PHB, thus allowing expression of $p h a / p h b$ genes once PHB synthesis is favored is not known.

The production of reserve material such as PHB has important metabolic features, since stress endurance and survival is improved when bacteria produce PHB, as observed for Azospirillum brasilense [5], and cells with high PHB content were able to increase the population 2-3 fold and survive for longer periods of starvation as seen in Sinorhizobium meliloti [6]. Therefore, knowledge of the PHB metabolism of plant-associated bacteria may contribute to the understanding of the colonization process and improvement of their resistance and survival under colonizing conditions.

\section{Conclusions}

Our results show that PhbF from H. seropedicae SmR1 binds to eleven promoter regions of genes related to PHB metabolism. A DNA-binding consensus sequence was determined and confirmed by DNase-I footprinting assay. Furthermore, expression of phbF::lacZ and phaP1::lacZ fusions indicated that PhbF may act as a transcriptional repressor of genes involved in PHB metabolism in H. seropedicae SmR1.

\section{Additional material}

Additional file 1: Figure S1: Circular dichroism spectrum of purified H. seropedicae His-PhbF. Figure S2: Gel filtration chromatography of purified H. seropedicae His-PhbF. Figure S3: Schematic organization of genes probably involved in polyhydroxyalkanoate (PHA) pathway and regulation in $H$. seropedicae. Figure S4: The DNA-binding assays of purified His-PhbF from $H$. seropedicae to the nifB promoter region (negative control).

\section{Acknowledgements \\ This research was financially supported by INCT - Fixação Biológica de Nitrogênio, CNPq, CAPES, Institutos do Milênio and PRONEX/Fundação Araucária. We thank Valter A. de Baura, Roseli Prado, Julieta Pie and Marilza Doroti Lamour for technical support. MASK and MMS held PhD and Post- doctoral fellowships from CNPq, respectively}

\section{Author details}

'Department of Biochemistry and Molecular Biology, Universidade Federal do Paraná, Curitiba - PR, Brazil. ²Department of Medical Pathology, Universidade Federal do Paraná, Curitiba - PR, Brazil.

\section{Authors' contributions}

MASK carried out cloning, expression, purification and EMSA of PhbF, participated in experimental design and drafted the manuscript. MMS carried out cloning, in vivo assays, participated in experimental design and drafted the manuscript. FGM carried out the DNase I-protection footprinting assay. RAM participated in DNA sequence analysis. EMS, FOP and LSC participated in experimental design, discussion and manuscript writing. MGY participated in manuscript drafting and correction. MBRS conceived of the study and participated in its design and coordination. All authors read and approved the final manuscript.
Received: 31 May 2011 Accepted: 14 October 2011

Published: 14 October 2011

\section{References}

1. Anderson AJ, Dawes EA: Occurrence, metabolism, metabolic role, and industrial uses of bacterial polyhydroxyalkanoates. Microbiol Rev 1990, 54(4):450-472.

2. Madison LL, Huisman GW: Metabolic engineering of poly(3hydroxyalkanoates): from DNA to plastic. Microbiol Mol Biol Rev 1999, 63(1):21-53.

3. Jendrossek D: Polyhydroxyalkanoate granules are complex subcellular organelles (carbonosomes). J Bacteriol 2009, 191(10):3195-3202.

4. Keshavarz T, Roy I: Polyhydroxyalkanoates: bioplastics with a green agenda. Curr Opin Microbiol 2010, 13(3):321-326.

5. Kadouri $D$, Jurkevitch $E$, Okon $Y$ : Involvement of the reserve material polybeta-hydroxybutyrate in Azospirillum brasilense stress endurance and root colonization. Appl Environ Microbiol 2003, 69(6):3244-3250,

6. Ratcliff WC, Kadam SV, Denison RF: Poly-3-hydroxybutyrate (PHB) supports survival and reproduction in starving rhizobia. FEMS Microbiol Ecol 2008, 65(3):391-399.

7. Hervas AB, Canosa I, Santero E: Transcriptome analysis of Pseudomonas putida in response to nitrogen availability. J Bacteriol 2008, 190(1):416-420.

8. Babel W, Ackermann JU, Breuer U: Physiology, regulation, and limits of the synthesis of poly(3HB). Adv Biochem Eng Biotechnol 2001, 71:125-157.

9. Steinbuchel A, Hein S: Biochemical and molecular basis of microbial synthesis of polyhydroxyalkanoates in microorganisms. Adv Biochem Eng Biotechnol 2001, 71:81-123.

10. Griebel R, Smith Z, Merrick JM: Metabolism of poly-beta-hydroxybutyrate. I. Purification, composition, and properties of native poly-betahydroxybutyrate granules from Bacillus megaterium. Biochemistry 1968, 7(10):3676-3681.

11. Potter $M$, Steinbuchel A: Poly(3-hydroxybutyrate) granule-associated proteins: impacts on poly(3-hydroxybutyrate) synthesis and degradation. Biomacromolecules 2005, 6(2):552-560.

12. Potter M, Muller $\mathrm{H}$, Steinbuchel A: Influence of homologous phasins (PhaP) on PHA accumulation and regulation of their expression by the transcriptional repressor PhaR in Ralstonia eutropha H16. Microbiology 2005, 151(Pt 3):825-833.

13. Kuchta K, Chi L, Fuchs H, Potter M, Steinbuchel A: Studies on the influence of phasins on accumulation and degradation of PHB and nanostructure of PHB granules in Ralstonia eutropha H16. Biomacromolecules 2007, 8(2):657-662.

14. Neumann L, Spinozzi F, Sinibaldi R, Rustichelli F, Potter M, Steinbuchel A: Binding of the major phasin, PhaP1, from Ralstonia eutropha H16 to poly(3-hydroxybutyrate) granules. J Bacteriol 2008, 190(8):2911-2919.

15. Prieto MA, Buhler B, Jung K, Witholt B, Kessler B: PhaF, a polyhydroxyalkanoate-granule-associated protein of Pseudomonas oleovorans GPo1 involved in the regulatory expression system for pha genes. J Bacterio/ 1999, 181(3):858-868.

16. Maehara A, Taguchi S, Nishiyama T, Yamane T, Doi Y: A repressor protein, PhaR, regulates polyhydroxyalkanoate (PHA) synthesis via its direct interaction with PHA. J Bacteriol 2002, 184(14):3992-4002.

17. Potter M, Madkour MH, Mayer F, Steinbuchel A: Regulation of phasin expression and polyhydroxyalkanoate (PHA) granule formation in Ralstonia eutropha H16. Microbiology 2002, 148(Pt 8):2413-2426.

18. Timm A, Steinbuchel A: Cloning and molecular analysis of the poly(3hydroxyalkanoic acid) gene locus of Pseudomonas aeruginosa PAO1. Eur J Biochem 1992, 209(1):15-30.

19. Matsusaki H, Manji S, Taguchi K, Kato M, Fukui T, Doi Y: Cloning and molecular analysis of the Poly(3-hydroxybutyrate) and Poly(3hydroxybutyrate-co-3-hydroxyalkanoate) biosynthesis genes in Pseudomonas sp. strain 61-3. J Bacteriol 1998, 180(24):6459-6467.

20. Sun J, Peng $X$, Van Impe J, Vanderleyden J: The $n t r B$ and $n \operatorname{tr} C$ genes are involved in the regulation of poly-3-hydroxybutyrate biosynthesis by ammonia in Azospirillum brasilense Sp7. Appl Environ Microbiol 2000, 66(1):113-117.

21. Kessler B, Witholt B: Factors involved in the regulatory network of polyhydroxyalkanoate metabolism. J Biotechnol 2001, 86(2):97-104.

22. Peralta-Gil M, Segura D, Guzman J, Servin-Gonzalez L, Espin G: Expression of the Azotobacter vinelandii poly-beta-hydroxybutyrate biosynthetic 
phbBAC operon is driven by two overlapping promoters and is dependent on the transcriptional activator PhbR. J Bacteriol 2002, 184(20):5672-5677.

23. York GM, Stubbe J, Sinskey AJ: The Ralstonia eutropha PhaR protein couples synthesis of the PhaP phasin to the presence of polyhydroxybutyrate in cells and promotes polyhydroxybutyrate production. J Bacteriol 2002, 184(1):59-66.

24. de Eugenio LI, Galan B, Escapa IF, Maestro B, Sanz JM, Garcia JL, Prieto MA The PhaD regulator controls the simultaneous expression of the pha genes involved in polyhydroxyalkanoate metabolism and turnover in Pseudomonas putida KT2442. Environ Microbiol 2010, 12(6):1591-1603.

25. Castaneda M, Guzman J, Moreno S, Espin G: The GacS sensor kinase regulates alginate and poly-beta-hydroxybutyrate production in Azotobacter vinelandii. J Bacteriol 2000, 182(9):2624-2628.

26. Miyamoto CM, Sun W, Meighen EA: The LuxR regulator protein controls synthesis of polyhydroxybutyrate in Vibrio harveyi. Biochim Biophys Acta 1998, 1384(2):356-364.

27. Baldani Jl, Baldani VLD, Seldin L, Dobereiner J: Characterization of Herbaspirillum seropedicae Gen-Nov, Sp-Nov, a Root-Associated NitrogenFixing Bacterium. Int J Syst Bacterio/ 1986, 36(1):86-93.

28. Catalan Al, Ferreira F, Gill PR, Batista S: Production of polyhydroxyalkanoates by Herbaspirillum seropedicae grown with different sole carbon sources and on lactose when engineered to express the lacZlacY genes. Enzyme Microb Tech 2007, 40(5):1352-1357.

29. Pedrosa FO, Monteiro RA, Wassem R, Cruz LM, Ayub RA, Colauto NB, Fernandez MA, Fungaro MH, Grisard EC, Hungria M, et al: Genome of Herbaspirillum seropedicae strain SmR1, a specialized diazotrophic endophyte of tropical grasses. PLoS Genet 2011, 7(5):e1002064.

30. Sambrook J, Fritsch EF, Maniatis T: Molecular Cloning - a laboratory manual. Cold Spring Harbor, New York: Cold Spring Harbor Laboratory Press; , second 1989.

31. Klassen G, Pedrosa FO, Souza EM, Funayama S, Rigo LU: Effect of nitrogen compounds on nitrogenase activity in Herbaspirillum seropedicae SMR1. Can J Microbiol 1997, 43(9):887-891.

32. Spaink HP, Okker RJH, Wijffelman CA, Pees E, Lugtenberg BJJ: Promoters in the Nodulation Region of the Rhizobium leguminosarum Sym Plasmid Prl1ji. Plant Mol Biol 1987, 9(1):27-39.

33. Miller JH: Experiments in Molecular Genetics. Cold Spring Harbor, New York: Cold Spring Harbor Laboratory Press; 1972.

34. Bradford MM: A rapid and sensitive method for the quantitation of microgram quantities of protein utilizing the principle of protein-dye binding. Anal Biochem 1976, 72:248-254

35. Bailey TL, Williams N, Misleh C, Li WW: MEME: discovering and analyzing DNA and protein sequence motifs. Nucleic Acids Res 2006, 34(Web Server issue):W369-373

36. Berger E, Ramsay BA, Ramsay JA, Chavarie C, Braunegg G: PHB recovery by hypochlorite digestion of non-PHB biomass. Biotechnol Tech 1989, 3(4):227-232

37. Potter M, Muller $H$, Reinecke F, Wieczorek R, Fricke F, Bowien B, Friedrich B, Steinbuchel A: The complex structure of polyhydroxybutyrate (PHB) granules: four orthologous and paralogous phasins occur in Ralstonia eutropha. Microbiology 2004, 150(Pt 7):2301-2311.

38. Laemmli UK: Cleavage of structural proteins during the assembly of the head of bacteriophage T4. Nature 1970, 227(5259):680-685.

39. Chaves DF, Ferrer PP, de Souza EM, Gruz LM, Monteiro RA, de Oliveira Pedrosa F: A two-dimensional proteome reference map of Herbaspirillum seropedicae proteins. Proteomics 2007, 7(20):3759-3763.

40. Rego FG, Pedrosa FO, Chubatsu LS, Yates MG, Wassem R, Steffens MB, Rigo LU, Souza EM: The expression of nifB gene from Herbaspirillum seropedicae is dependent upon the NifA and RpoN proteins. Can J Microbiol 2006, 52(12):1199-1207.

41. Chou ME, Yang MK: Analyses of binding sequences of the PhaR protein of Rhodobacter sphaeroides FJ1. FEMS Microbiol Lett 2010, 302(2):138-143.

42. MacNeil T, MacNeil D, Tyler B: Fine-structure deletion map and complementation analysis of the $g \ln A-g \ln L-g \ln G$ region in Escherichia coli. J Bacteriol 1982, 150(3):1302-1313.

43. Pedrosa FO, Teixeira KRS, Machado IMP, Steffens MBR, Klassen G, Benelli EM, Machado HB, Funayama S, Rigo LU, Ishida ML, et al: Structural organization and regulation of the nif genes of Herbaspirillum seropedicae. Soil Biology \& Biochemistry 1997, 29(5-6):843-846.
44. Kleiner D, Paul W, Merrick MJ: Construction of Multicopy Expression Vectors for Regulated over-Production of Proteins in Klebsiella pneumoniae and Other Enteric Bacteria. J Gen Microbiol 1988, 134:1779-1784

doi:10.1186/1471-2180-11-230

Cite this article as: Kadowaki et al:: Identification and characterization of PhbF: A DNA binding protein with regulatory role in the PHB metabolism of Herbaspirillum seropedicae SmR1. BMC Microbiology 2011 $11: 230$

\section{Submit your next manuscript to BioMed Central and take full advantage of:}

- Convenient online submission

- Thorough peer review

- No space constraints or color figure charges

- Immediate publication on acceptance

- Inclusion in PubMed, CAS, Scopus and Google Scholar

- Research which is freely available for redistribution 